\section{Inytsky D., Zinchenko S., Savych 0., Yanchetskyy $\mathbf{0}$.}

\title{
ANALYSIS OF SEAPORTS DEVELOPMENT STRATEGIES: SCIENCE, TECHNOLOGY, EDUCATION AND MARKETING
}

Об’єктом дослідження є розвиток морських портів за умов загострення глобальної конкуренції, реалізацї конкурентами агресивних політик та стратегій. Найбільш проблемними аспектами підвищення ефективності виконання морсвкими портами сучасних функцій (інтеграційної, обслуговуючої, іміджевої) є ігнорування інтересів ключових стейкхолдерів, недостатнє використання всіх чинників розвитку. А також брак усвідомлення глобальних трендів та конкурентних умов розвитку інфраструктури морського транспорту та його взаємозв'язків з наземною інфраструктурою, та вади пріоритетів, що закладені в стратегіях.

В ході дослідження вивчалися наукові та аналітичні праці стратегій розвитку морсвких портів на рівні галузей та підприємств. А також використовувалися методика побудови конкурентних карт глобального портового ринку, систематизація чинників і узагальнення сучасних методик дослідження закономірностей та особливостей розвитку морських портів, та аналіз мікро- та макроекономічних показників їх діяльності.

В результаті в роботі визначено коло стейкхолдерів розвитку морських портів, запропоновано матрицю чинників їх розвитку та побудовано конкурентні карти світового портового ринку з позиціями країн і портів. Аналіз конкурентних карт виявив значні асиметрії у динаміці та розмірах ринкових часток морських портів та країн на світовому портовому ринку, що є результатом реалізації унікальних національних, регіональних та місцевих стратегій. Ключовим рушієм їх розвитку визначено активне використання державно-приватного партнерства, науково-освітніх, технологічних і маркетингових чинників. Виявлено глобальні тренди (контейнеризація, екологізація та децентралізація) та запропоновано рекомендацї щодо ключових аспектів розвитку:

- перегляд ролі держави;

- врахування інтересів ключових стейкхолдерів;

- дерегуляція;

- поєднання системного та індивідуального підходів до кожного порту;

- підвищення якості моніторингу і взаємозв'язів з науково-освітньою системою;

- застосування маркетингового інструментарію. Їх імплементація у стратегї розвитку дозволить підвищити довгострокову ефективність функціонування морських портів Украйни та пов'язаних галузей.

Ключові слова: транспортна інфраструктура, світовий портовий ринок, конкурентна карта ринку, умови дерегуляиіи.

\section{Introduction}

The development of European transport corridors, especially between the Baltic and Black Seas, the EU countries and Asia, is bypassing Ukraine. This fact and low regional competitiveness of Ukrainian seaports cause a decline in the competitive positions of companies and the economy of the country, a negative impact on GDP dynamics. One of these challenges is the announcement of plans for the revival of the Great Silk Road outside Ukraine's borders. Moreover, the quality of the development of the logistics infrastructure of Ukraine, without which the development of the internal market and access to the external one is extremely difficult, is only $56 \%$ of the world level, which corresponds to 71 places in the world [1].

The example of developed countries (USA, France, the Netherlands, etc.) and many developing countries in Asia (China, South Korea, Vietnam) demonstrates the need to provide targeted investments for the seaports' development. The infrastructure of seaports should provide an opportunity to use effectively the potential of the international division of labor, world markets and national economies for socio-economic development. The functioning of Ukraine's seaports is based on a basis, the formation of which took place over a long period of time, using technologies and management models that have been significantly improved abroad.

Investments in the seaports' development often face the dilemma of choosing between strategies to increase productivity or increase core infrastructure [2]. In such situations, regardless of the form of ownership (private or public), the decision must be based on calculations (including forecasting and economic and mathematical modeling, which includes many factors). Moreover, in cases with private investors, decisions should include project payback calculations. Obviously, the peculiarities of the economic-geographical situation, natural conditions also influence the development conditions of each particular port and, accordingly, its market positions.

However, these and other challenges in Ukraine have not been properly resolved in the development strategy of seaports. These arguments stipulate the need to improve the strategy for the development of the seaports of Ukraine on the basis of the modern methodological base, the results of the latest scientific and applied research. 


\section{The object of research and its technological audit}

The object of research is the seaports' development in conditions of increasing global competition and the implementation of aggressive policies and strategies by competitors.

Analysis of the state of the seaports of Ukraine in comparison with foreign competitors gives grounds to talk about the prospect of revising their development strategy. Concerning the issues of audit of financial statements and technological status to certified specialists, let's carry out analysis based on available secondary documents. The net financial result of the functioning of Ukraine's seaports and the dynamics of freight flows over the last three years show a negative trend (Table 1). The aggregate assets and uncompleted capital investments of seaports were negatively affected by the sharp drop in the hryvnia exchange rate.

Among the priorities of the development of the Ukrainian economy, national interest (apart from increasing the export of goods with high added value) is represented by the diversification of energy sources and other resources, which is impossible without the development of opportunities for their supply by sea. However, over the years of independence, decisive steps towards the development of specialized energy terminals have not been undertaken, which is demonstrated by the indicators of recent years (Table 1). For comparison - the income of the port of Los Angeles (1.62\% of the world market) in 2017 amounted to 474 million USD and its assets -4678 billion USD [3]. The dynamics of the financial indicators of the development of Ukraine's seaports shows a decline in the value of assets as a result of the hryvnia devaluation, a 3.5-4-fold drop in the amount of uncompleted capital investments. However, at the same time, the increase in net income and the financial result of Ukrainian seaports seems to be paradoxical, which is a temporary consequence of the severe savings on the staff compensation fund.

Seaports of Ukraine for the past 6 years have demonstrated different dynamics of transportation (Fig. 1), which confirms the need for an individual approach to the development of each of them. At the same time, the analysis of the dynamics of transit traffic of Ukraine's seaports shows that since 2012, there has been a drop in transit volumes in all ports. This indicates a worsening of positions in the world market, which is confirmed by Ukraine's position on the competitive map of the world market. For six years, the overall decline was more than 2.5 times, which was due, above all, to the effects of structural changes in the economy and the political and economic situation in the region. Only in 2016 in some seaports there has been a tendency to restore the level of transit traffic.

Based on the data of the Administration of the seaports of Ukraine, the fields for the reserve of cargo processing in ports were built. The reserve of cargo turnover of the seaport (the difference between its maximum and minimum value for the period under consideration) for the smallest port of Berdiansk is 2439.9 tons, for the largest port of Yuzhne - 9009.6 tons. According to the estimates of the authors, the reserves of individual Ukrainian seaports reach $65 \%$ their turnover. Thus, the reserve fields fully demonstrate the capabilities of the transport systems of Ukraine's seaports in conditions of volatility in the volumes of transportation of various cargoes. Obviously, a larger port has a greater stability reserve during the period of cyclical fluctuations, and in relative terms, fluctuations in cargo volume of a large port are much less than for a small one. It can be assumed that large ports of Ukraine in a difficult economic environment will work more stable than small ones, which, under deregulation, require special, increased attention from the state, investors and other stakeholders.

Table 1

The main financial indicators of the seaports' development in Ukraine, mln

\begin{tabular}{|l|c|c|c|c|c|c|}
\hline \multicolumn{1}{|c|}{ Indicator } & Currency & 2013 & 2014 & 2015 & 2016 & 2017 \\
\hline \multirow{2}{*}{ Total assets } & UAH & 16656 & 17483 & 20639 & 20682 & 21517 \\
\cline { 2 - 7 } & USD & 2084.6 & 1109.3 & 860.0 & 760.6 & 766.8 \\
\hline $\begin{array}{l}\text { Unfinished capi- } \\
\text { tal investments }\end{array}$ & UAH & 3676 & 2817 & 3133 & 3418 & 3944 \\
\cline { 2 - 7 } & USD & 460.1 & 178.7 & 130.5 & 125.7 & 140.6 \\
\hline \multirow{2}{*}{ Net income } & UAH & 1870 & 4004 & 6810 & 7297 & 7633 \\
\cline { 2 - 7 } & USD & 234.0 & 254.1 & 283.8 & 268.4 & 272.0 \\
\hline $\begin{array}{l}\text { Net financial } \\
\text { result }\end{array}$ & UAH & 647 & 1512 & 3847 & 3854 & 3605 \\
\cline { 2 - 7 } & USD & 81.0 & 95.9 & 160.3 & 141.7 & 128.5 \\
\hline $\begin{array}{l}\text { USD exchange rate at the } \\
\text { end of the year }\end{array}$ & 7.99 & 15.76 & 24.00 & 27.19 & 28.06 \\
\hline
\end{tabular}

Note: compiled according to the financial statements of the Administration of Seaports of Ukraine [4].

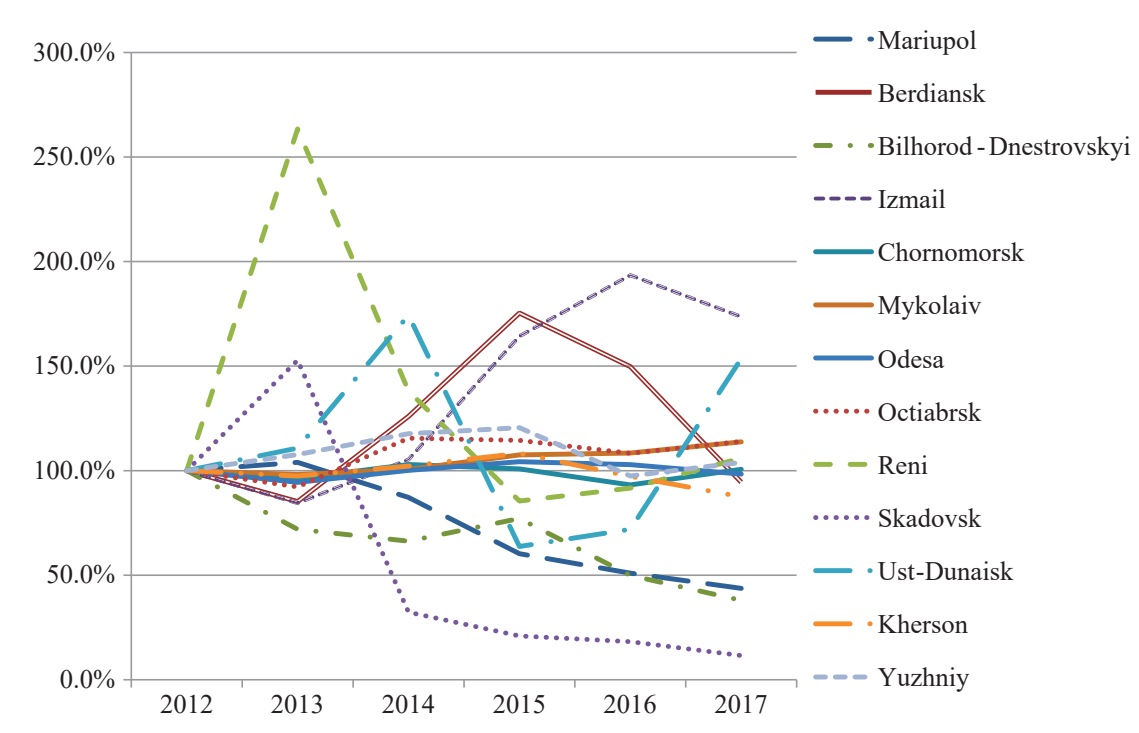

Fig. 1. Dynamics of freight traffic in the ports of Ukraine $(2012=100 \%)$ (compiled by the authors according to [5])

The seaports of Ukraine should prepare for changes in the structure of transported cargoes and used fuels, which, under the pressure of the paradigm of sustainable 
development, are caused by the need to green the economic development. Most researchers agree that of all the options for developing more environmentally friendly types of marine fuel (offshore oil, heavy oil and exhaust gases, liquefied natural gas (LNG) and methanol), priority is given to LNG. The massive use of LNG will help to reduce $\mathrm{CO}_{2}$ emissions by $15-20 \%$ [6] (the reduction of the vessel's speed and the increase in their capacity are also contributing to the reduction of $\mathrm{CO}_{2}$ emissions [7]). One of the major obstacles to the LNG introduction (apart from a lack of real investment) is the lack of necessary resources in the field of maritime education, as well as weak inter-institutional links between education and business. In the US and the EU also agree that the training of personnel affects the security, operations in the mass use of gas as fuel in ports and maritime transport [8].

It is believed that the leader of the introduction of high environmental standards is Norway, as well as Scandinavian countries and the most developed countries, whose seaports and transport will primarily give priority to LNG. Thus, the Baltic region can become a global environmental leader, which is extremely important for the regions of the Black and Mediterranean seas, as recreationally attractive regions. It is the development of the services sector based on the principles of sustainable development with the use of recreational and tourist advantages that is one of the likely prospects for the further development of the Ukrainian economy.

At this time, Ukraine's position in the container transportation market is extremely weak. The development of container transportations, as well as their poor use in the Black Sea, and especially the Sea of Azov, forms a challenge and the possibility of establishing regional hubs in the seaports of Ukraine. Italian scientists suggest using mathematical programming models to optimize the placement of container terminals [9]. At the same time, it is necessary to take into account not only the world experience, but also the peculiarities of the network of national and international continental transport corridors.

The significant unused potential of Ukraine's seaports and the decline in their assessment (Table 1, Fig. 1) necessitate the development and implementation of a strategy aimed at increasing their contribution to GDP growth. The development of Ukraine's seaports is facing the problem of decentralization, which is also characteristic of the development of domestic universities. Universities and seaports, being really more autonomous institutions, are able to respond effectively to dynamic challenges, implement marketing strategies, and influence the development of other economic agents. The various development trajectories of ports (Fig. 1) confirm the need for liberalization of the conditions for their development.

Disadvantages of the seaports' development in Ukraine also include the lack of a system of scientific and analytical support of activities, monitoring of local and global challenges, for example, market, environmental or technological. Such monitoring system should identify trends and form a basis for research on the possibilities of effective response to them.

Disadvantages of the seaports' development are also visible by analyzing the existing strategy for their development. It is a formal short-term program that does not take into account the interests of all stakeholders, global challenges and the experience of other countries in developing strategies in this sector. In fact, its goal is not defined, which could consist in doubling the contribution to socio-economic development. The long-term impact of implementing the strategy, which is calculated for more than 15 years, calls for a broad discussion not only among a narrow circle of industry specialists, but also scientists, analysts, politicians and entrepreneurs. In addition, the issues of providing investment, scientific, human resources and flexible response to market challenges have not been sufficiently worked out. One of the most problematic places is the lack of revision of the role of the state in the seaports' development.

\section{The aim and objectives of research}

The aim of research is substantiation of the strategic components of the seaports' development on the basis of studying the modern methodological base, the state of development of the world market and best practices.

To achieve this aim it is necessary to accomplish the following tasks:

1. To systematize factors of the seaports' development.

2. To outline the range of stakeholders.

3. To build a competitive map of the world port market and identify its leaders, including the position of Ukraine.

4. To substantiate the key directions of competitiveness management of Ukrainian seaports, which can be incorporated into the strategy of their development.

5. To identify features of ensuring the integrity of the chain of science - technology - education - marketing.

\section{Research of existing solutions of the problem}

Especially the solution of these problems is promising in the conditions when the development of the European transport corridors is carried out bypassing Ukraine. At the same time, the low regional competitiveness of Ukrainian seaports causes a decline in the competitive positions of the Ukrainian economy. The rhythm of the seaports' operation provides stability in the work of the regions adjacent to them, which is evident from the development of the world's leading ports.

Since 1980, the most active period has been the period since 2008 , when the number of studies on the competitiveness components of ports included the largest number of elements [10]. Since 2000, the number of publications has a constant tendency to increase, which is due not only to the need for decision-making on the basis of research, but also to the growing attention to ports as important nodal binding economic agents (Table 2). It is in recent years that the struggle for the use of transport infrastructure as a factor of access to domestic markets has been exacerbated.

In many publications, various features and trends in the development of the world's seaports have been identified, but they have not been adequately generalized [12-16]. The role of container transport is invaluable in the activities of a modern seaport, which will further increase in the structure of port operations and the impact that economic development has on [17, 18]. Further development of this type of transportation in different countries has national characteristics, which are often the subject of research [5, 19-21]. 
Dynamics of the number of publications on port topics, units

\begin{tabular}{|c|c|c|c|c|c|c|}
\hline \multirow{2}{*}{$\begin{array}{c}\text { 5earch } \\
\text { attributes/period }\end{array}$} & \multicolumn{2}{|c|}{ Search word «port» } & \multicolumn{2}{|c|}{ Search word «seaport» } & \multicolumn{2}{|c|}{ Search word "port competition» } \\
\hline & $\begin{array}{c}\text { by name, keywords } \\
\text { and abstracts }\end{array}$ & by all fields & $\begin{array}{l}\text { by name, keywords } \\
\text { and abstracts }\end{array}$ & by all fields & $\begin{array}{l}\text { by name, keywords } \\
\text { and abstracts }\end{array}$ & by all fields \\
\hline Total & 25229 & 805193 & 413 & 5842 & 453 & 59062 \\
\hline 2018 & 691 & 97 & 12 & 175 & 175 & 940 \\
\hline 2017 & 1902 & 2409 & 45 & 430 & 430 & 2381 \\
\hline 2016 & 1754 & 22182 & 55 & 399 & 399 & 2105 \\
\hline 2015 & 1704 & 21528 & 42 & 351 & 351 & 1993 \\
\hline 2014 & 1554 & 20145 & 37 & 314 & 314 & 1902 \\
\hline 2013 & 1382 & 19939 & 30 & 278 & 278 & 1805 \\
\hline 2012 & 122 & 18241 & 26 & 194 & 194 & 1554 \\
\hline 2011 & 1189 & 17928 & 26 & 195 & 195 & 1476 \\
\hline 2010 & 1105 & 16437 & 14 & 153 & 153 & 1319 \\
\hline 2009 & 105 & 16942 & 11 & 187 & 187 & 1365 \\
\hline 2008 & 938 & 16707 & 10 & 145 & 145 & 1441 \\
\hline 2007 & 806 & 16395 & 9 & 154 & 154 & 1348 \\
\hline 2006 & 773 & 15869 & 14 & 143 & 143 & 128 \\
\hline 2005 & 711 & 14929 & 6 & 105 & 105 & 1128 \\
\hline 2004 & 712 & 13682 & 10 & 115 & 115 & 102 \\
\hline 2003 & 606 & 12661 & 4 & 80 & 80 & 1026 \\
\hline 2002 & 532 & 11158 & 6 & 86 & 86 & 978 \\
\hline 2001 & 527 & 11358 & 2 & 70 & 70 & 990 \\
\hline 2000 and before & 6072 & 61057 & 54 & 333 & 333 & 33010 \\
\hline
\end{tabular}

Note: compiled by the authors on the basis of materials [11]

Methodological bases have the majority of publications, however, modern methods of analyzing the effectiveness of seaports (multicriteria and others) [22-24] should be especially emphasized. Increasing the role of science and education in ensuring the effectiveness of the activities of seaports leads to the implementation of unique corporate strategies, the experience of which can be transferred to the national level [25]. Especially it is necessary to single out works that focused on various theoretical and practical aspects of port functioning - integration, logistics, technological, regional, operational and environmental [26-30].

Technologies for the seaports' development are very diverse and, as a rule, publications consider only one taken from them. They are talked about when studying the issues of operation and repair of seaport facilities [26]. The interaction of dry and seaports is analyzed in [9, 31-33]. New energy-efficient types of cargo transportation are considered mainly on the example of developed countries [6, 8, 34]. A similar conclusion is drawn from the consideration of the environmental aspects of the seaports' operation [28]. In addition, significant dimensions of the use of technology in the development strategies of seaports are provided by their size [7, 35, 36].

Different regions of the world economy are represented to a varying degree in publications devoted to the seaports' development. Most of the studies consider the activities of the largest and fastest-growing seaports in Europe, North America and North Africa, and South-East Asia [37-41].

Development of infrastructure industries, which are often natural monopolies, cease to be exclusively an in- ternal affair of modern countries. Sea transportations are initially characterized by significant internationalization, which, under the conditions of globalization, significantly affects the development strategy of seaports as an industry and business. In the opinion of the authors of some works, logistics of cargo transportation affects the strategy of development of marine ports [29, 42, 43]. Public-private partnerships are often seen as an instrument to increase the participation of private capital in the development of infrastructure industries [44-48]. At the same time, increasing the competitiveness of ports is rare, but more and more often in recent years is encountered among researchers' tasks [27, 49, 50].

Thus, the results of the review of publications allow to conclude that the problem of analyzing the strategies for the seaports' development is not new in world science, has been investigated in various aspects. However, there was no comprehensive generalization of the system of factors and trends in the seaports' development, identification and management of their competitive positions, and their implementation in the form of national or corporate strategies.

Predominantly the issues of the seaports' development are rather closed questions of practical analytics and internal priorities. Increasing the effectiveness of modern strategies for the seaports' development and the industry as a whole should take into account the results of the evolution of scientific thought and practice. This makes it necessary to update the theoretical base, identify new patterns and features of the development of Ukraine's seaports. 


\section{Methods of research}

The methodological basis for the seaports' development is a synthesis of such key trends in modern science as the paradigm of technological development, institutionalism, the theory of the world market, regionalism and international integration, micro- and macroeconomics, the concept of sustainable development. Most often, the subjects that take part in the seaports' development and consume their services are called:

- state (as a regulator, a developer of policies, a consumer);

- customers (trading and transport-logistics companies);

- service companies and third parties that provide

related services;

- owners of capital;

- guarantors and insurers;

- management and managers of the port;

- workers and trade unions.

Visualization of the circle of stakeholders, the main vectors of influence and the forms of their interaction allows in practice to make more weighted decisions (Fig. 2). It should be borne in mind that in each specific case, their collection will be unique in terms of the distribution of influence - direct or indirect, which will probably necessitate a review of the forms of interaction. Realizing that each seaport is a unique model of the functioning of an infrastructure facility in specific monopoly conditions (temporary, natural-geographic, socio-economic, technological, resource, market, personnel, etc.), researchers use different methodological approaches.

The priority task is the need to outline the full range of stakeholders that such entities form:

- state as the owner and regulator, in the person of national transport ministries, agencies of exploitation and development of port infrastructure, customs authorities; - local authorities (region, city);

- stevedoring, transport and logistics companies, line operators and their customers;

- managers and workers, trade unions and public organizations;

- owners of land and investment resources, financial intermediaries;

- manufacturers of vehicles, equipment, containers, building materials and other products;

- service companies, including from such sectors as public catering, tourism, recreation;

- scientific and educational institutions, primarily universities and think tanks;

- international organizations, primarily the International Maritime Organization (IMO), the International Organization for Standardization (ISO), global and international navigation systems;

- other participants in transport corridors, clusters, supply chains and value-added, including ports-competitors and partner ports.

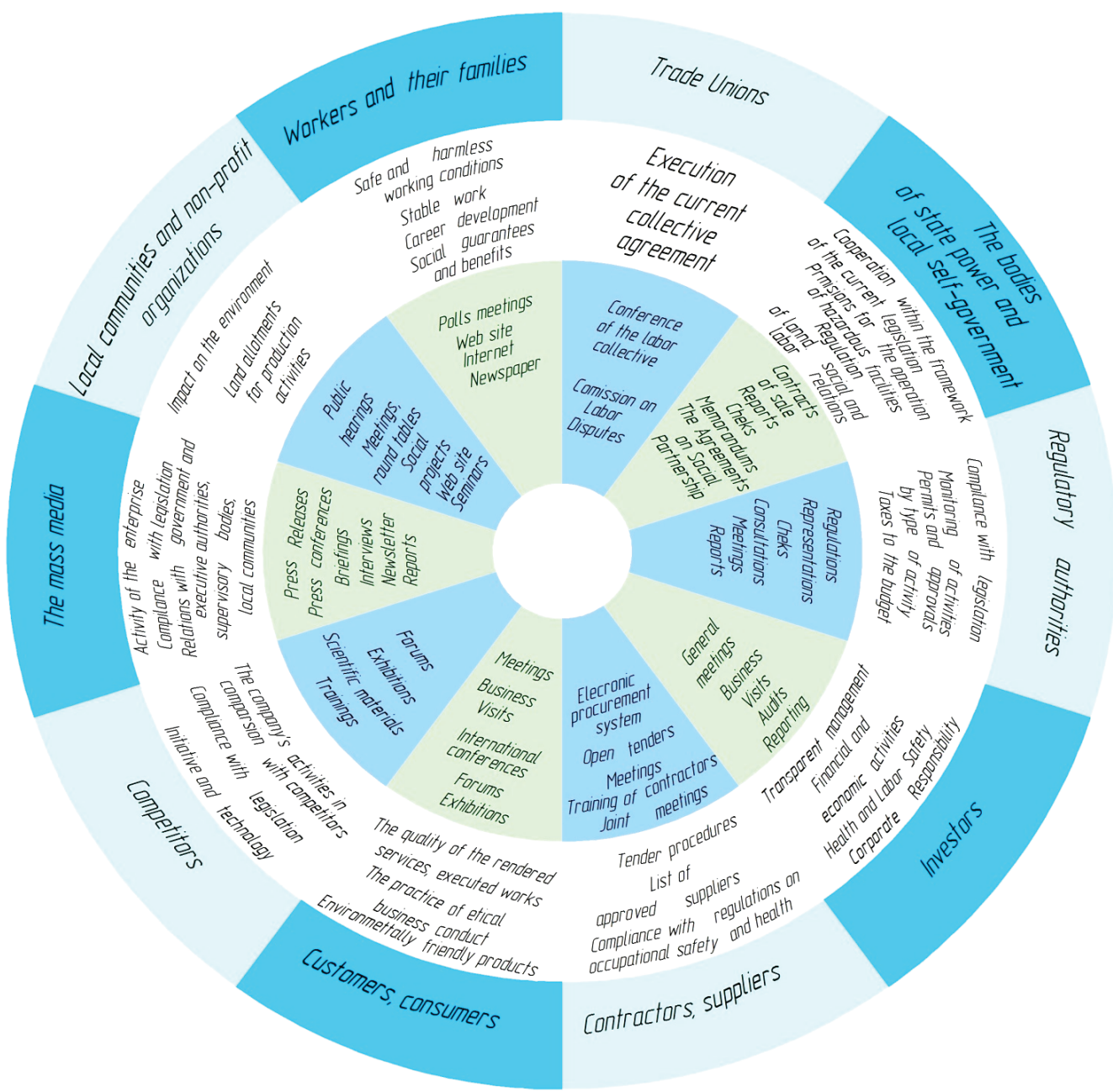

Fig. 2. The main stakeholders, the vectors of influence and the forms of their interaction on the example of the Mariupol Commercial Seaport (Ukraine) 
The use of the analytical hierarchy process on the example of functions and port ownership allowed to identify a number of models of public-private cooperation - the landlord model, the state owner model and the privatization business model [38]. The most common models of seaports' development are Smart Port Initiative, Landlord Port, Workport and hub ports. In UNCTAD (the United Nations Conference on Trade and Development), different generations of port development are also identified, depending on freight flows, functions and development factors, as well as levels of functional integration (formation, expansion, specialization and regionalization) [35].

Linear and nonlinear models, as well as the transformation of nonlinear to linear, are traditionally used to study the patterns and features of the development of transport infrastructure [39]. Network models and methods for determining key performance indicators are most often used to compare port terminals in terms of size, processing equipment, runtime, capacity and other attributes [40]. They are effective for selection of customers and forwarders of a specific terminal, which represents a marketing interest from considerations of supply chain development, decision-making by users of port terminals. To visualize the results, researchers use a matrix of pairwise comparison of indicators, which assign weight coefficients, which allows them to be ranked. The use of game theory has made it possible to identify the key factors of seaport choice, which are the port size, as well as the incentive system [36].

A logical continuation of the ranking is the compilation of various balanced assessments, indices (customer satisfaction index, financial index, cooperative ratio index, non-market instruments index) to which ratings can be added safely [31]. To measure the activity of using ports of trade facilitation tools to increase the production of provided services, researchers suggest using index calculation [41]. In this case, the components of the index are such components as:

1) port infrastructure;

2) port management;

3) customs procedures;

4) transparency of the implementation of customs legislation.

Science and education occupy an integral part of all high-end ratings. It should be noted that, depending on the trade direction (import or export), the share of the scientific and educational component in the index is from $12.9 \%$ to $13.6 \%$. Although in fact it is higher, because it is included in such indicators as, for example, security management and traffic management.

The attraction of investments and long-term loans to the seaports' development that are in the way of major international commodity flows is also based on techniques that comprehensively assess many factors. All of them using weighting factors are reduced to a single resulting indicator. One such example is the attraction of the resources of the Japan Agency for the Development of International Cooperation to the modernization of the Lithuanian port of Klaipeda, which since 1999 has been constantly increasing the volume of services [51].

On the other hand, the seaports themselves should also rely on certain analytical models to plan and forecast cargo flows. So the development of technologies and the changing priorities of social and economic development towards ecologization leave its imprint on the quantitative and qualitative characteristics of ports and terminals. For example, an imitation model is often used to determine the optimal amount of equipment for container handling [52]. The development of information technology also necessitates the use of software both in the current activities of the seaport and for conducting research. Modern management technologies for such complex systems as seaports rely on the use of information and information and communication technologies. So the Flow Map software, which is a combination of maps and flowcharts that show a simulation of the spatial movement of objects, can be used to identify the flow of goods, the traffic network and the speed of data migration, and conduct market research [22].

Strategic features also impose a vector of specialization of transported goods - export/import. Countries that traditionally occupy large niches in the world market should effectively use the opportunities of sea transport and port infrastructure (Table 3).

Table 3

Place of the main maritime countries in international trade in 2016, \%

\begin{tabular}{|c|c|c|c|c|}
\hline \multirow{2}{*}{ Country } & \multicolumn{2}{|c|}{ Share in world volume } & \multicolumn{2}{c|}{ Share in the country's GDP } \\
\cline { 2 - 5 } & Export $\downarrow$ & Import & Export & Import \\
\hline China & 13.15 & 9.78 & 19.6 & 17.4 \\
\hline USA & 9.12 & 13.88 & 11.9 & 14.7 \\
\hline Germany & 8.40 & 6.50 & 46.1 & 38.1 \\
\hline Japan & 4.04 & 3.74 & 16.1 & 15.1 \\
\hline Netherlands & 3.57 & 3.10 & 82.4 & 71.4 \\
\hline South Korea & 3.11 & 2.50 & 42.2 & 35.4 \\
\hline United Kingdom & 2.57 & 3.92 & 27.9 & 30.1 \\
\hline Mexico & 2.34 & 2.45 & 38.2 & 40.0 \\
\hline Singapore & 2.07 & 1.74 & 172.1 & 146.3 \\
\hline Australia & 1.19 & 1.21 & 18.9 & 21.1 \\
\hline Malaysia & 1.19 & 1.04 & 67.7 & 61.0 \\
\hline Brazil & 1.16 & 0.88 & 12.5 & 12.1 \\
\hline Russia & 1.77 & 1.18 & 25.7 & 20.6 \\
\hline India & 1.65 & 2.21 & 19.2 & 20.6 \\
\hline Ukraine & 0.23 & 0.24 & 49.3 & 55.5 \\
\hline Egypt & 0.16 & 0.34 & 10.3 & 19.7 \\
\hline The world average & - & - & 28.5 & 27.8 \\
\hline
\end{tabular}

Note: compiled according to $[12,13]$.

In addition, in historic port cities, it is necessary to take into account the waves and vibrations created by ships, and in large ports - the traffic of smaller ships and yachts, the impact on the entire ecosystem. Therefore, the implementation of large infrastructure projects, such as seaports, should use multi-criteria analytical models, for example, as in Venice [23].

The increase in the location of dry ports for the seaport's development is based on qualitative results obtained using the Delphi methodology and a multi-criteria analysis of assessing the quality of port locations [24]. It is complemented by the use of the recursive gray operation method, which, for example, allows measuring the effectiveness of cooperation between a group of dry and seaports [31]. 
The functioning and development of ports should be viewed from the point of view of their effectiveness, which is particularly promising for the development of development strategies and programs. An example can be the use of multicriteria analysis on the basis of such groups of criteria [22]:

1) local spatial system;

2) national transport system;

3) national security;

4) operational and technical characteristics;

5) types of goods;

6) port services;

7) cost of logistics services.

For example, there are significant differences in the value added associated with the categories of handled goods. Dry mass and liquid volume usually generate more limited added value per ton, and when they are transshipped, price competition is more characteristic than for design, general and container cargo. The analysis of value added by types of cargo in US ports shows that the values can differ up to 10 times: one ton of processed grain generates an average of 20 USD, cars - 220 USD, and container loads 90 USD [14]. The adoption of strategic decisions should also take into account the results of SWOT analysis.

To study the performance of ports, Promethee technique is often used, which is especially important for performance evaluation [19]. Moreover, benchmarking can be used to assess the effectiveness of functions and key indicators [31].

However, it should be noted that its use should be based on obtaining indicators on the basis of a single methodological base, which is a significant problem also for most known methods of port research.

Researchers confirm the assumptions that for carrying out international comparisons, benchmarking, there is insufficient statistical data obtained on one methodological basis [44]. The main methodological methods of research are a literature review, an expert survey, a case study and analysis. However, one of the universal indicators should recognize the volume of transshipment of goods for a certain period (usually 1 year). Even in such conditions, we meet with some differences - in practice, let's use units such as freight, metric and revenue ton.

From the point of view of the seaport as a business, the most important is the rationale for ways to increase competitiveness, which should be based on the use of certain techniques [49]. One of these is the construction of competitive chards that allow to identify the positions of competitors in a particular market. In general, the researchers agree that in specific cases, depending on applied purposes, the rationale for hybrid research models is optimal, especially based on the use of the TOPSIS method (Technique for Order of Preference by Similarity to Ideal Solution) and the process of the analytical hierarchy [20]. In general, the main groups of criteria for assessing the competitiveness of seaports include public and market communications, information technology, environmental development, engineering, cruise and navigation support, management effectiveness.

\section{Research results}

The systematization of the factors of the seaports' development made it possible to formalize them in the form of a matrix that demonstrates the complexity of the interrelationships of factors and development priorities that form national and corporate models (Table 4). Depending on the level of development of the country, the regulatory model and the port itself, various aspects become the priorities, as will be demonstrated by the examples of the conducted studies. A special place in the system of factors is occupied by land as the least mobile factor, but which should be used effectively.

Matrix of seaports' development factors

Table 4

\section{Thenponents}

\begin{tabular}{|l|c|c|c|c|c|}
\multirow{2}{*}{} & \multicolumn{5}{|c|}{ Components } \\
\cline { 2 - 6 } & Capital & $\begin{array}{c}\text { Land and } \\
\text { water area }\end{array}$ & Staff & $\begin{array}{c}\text { Information } \\
\text { (knowledge) }\end{array}$ & $\begin{array}{c}\text { Entrepreneurial } \\
\text { competencies }\end{array}$ \\
\hline rnal & + & - & + & + & + \\
\hline nal & + & + & + & + & + \\
\hline Technological & + & +- & + & + & + \\
\hline Market & + & + & + & + & + \\
\hline Environmental & + & + & + & + & + \\
\hline Social & + & + & + & + & + \\
\hline
\end{tabular}

Containerization of maritime transport, development of international trade, technological progress of intermodal transport, concentration in the maritime industry, and liberalization of transport markets are trends that lead to increased activity of users of port services. Under conditions where according to the World Trade Organization (WTO) about $80 \%$ of world trade is carried out by sea, an analysis of the relationship between the shares of countries in world trade and in container transportation shows that it tends to strengthen. So the correlation coefficients for the data for 2010 were 0.790 ; for 2013 0.816 ; for $2016-0.829$.

Among the trends in the development of port infrastructure, a special place is taken by increasing attention to environmental aspects, which in the coming decades will be of decisive importance both for the infrastructure itself and for transport. Ensuring sustainable development is actualized not only in developed countries, but also in Asian countries.

The study of the environmental aspects of the development of the ports of China, India, South Korea, and Thailand revealed that the most important for minimizing the negative impact on the environment is the provision of reliable rail communication of the seaport with inland territories [32]. This, in turn, raises questions of the development of the entire national transport system with the participation of enterprises of all forms of ownership, technological and personnel readiness. However, sea container ports, having developed railway communication, also depend on the quality of roads in the regions they serve [21].

6.1. World market map. The study allows to build competitive maps of the world market of port services on the basis of two indicators - the gross volume of traffic in tones (Tables 5,6) and the volume of container 
transportation to TEU (Tables 5-7). The first indicator characterizes all types of cargo, and the second - those that are transported in containers and which are characterized by higher added value. In general, the maps demonstrate the presence of dynamic competitive conditions for the development of the market and, accordingly, the industry. And the leading positions are occupied by those ports and countries that have implemented development strategies for the last ten years taking into account all the outlined factors. The positions of the countries correspond to their place in the world market (Table 3), except for Germany, which carries a significant part of the commodity flows overland and actively uses the capabilities of foreign seaports.

Together, the 213 ports analyzed in both 2010 and 2015 provided $87 \%$ of the world's container shipping market, which volumes increased by a quarter in the last six years alone. And according to the forecasts of the McKinsey Global Institute, the 50-year forecast of which was justified in 1967, container shipments up to 2067 compared to 2017 can grow from 2.5 to 4.5 times depending on the prospects for the world economy [17]. It is expected that the transportation will be so based on technologies that will practically become independent of the individual, which will require the effective use of all factors (Table 4).

It is believed that the closer seaports of one or different countries are located, the more severe competition between them for customers and partners [36]. However, analysis of the competition development in the world market has shown that its intensity is invariably high enough. The largest 10 seaports in aggregate controlled $35.6 \%$ of the container transport market both in 2008 and in 2015, and 50 large seaports -70.9 and $71.2 \%$, respectively. Similar conclusions about intensity are confirmed both for transportations, which are measured in tons, in individual seaports, and at the scale of country comparison. Although the main competitors practically do not leave the market, the advantages are primarily users of higher-quality port services that affect the economic development of countries.

The analysis of the liner message index confirms the obtained results. It provides an opportunity to group countries, among which the leading maritime powers can be called China, Singapore, South Korea, Malaysia, the Netherlands, the USA, Germany, Belgium, Britain and Spain [15]. These countries are estimated to occupy a significant share of the world market, respectively - 29.8, $3.2,6.0,2.3,3.4,10.9,1.6,1.5,1.8$ and $1.9 \%$ (in the aggregate $-62.4 \%$ ).

An analysis of the competitiveness of the port cities reveals a global trend in the shift in the global distribution of forces in this world market. If in 1972 about $40 \%$ of the world's activities of seaports were carried out in Europe, $20 \%$ in North America and $20 \%$ in Asia, then by 2009 the situation changed dramatically - in Asia more than $50 \%$ of the world activity of seaports occurred, about $20 \%$ in Europe and $10 \%$ in North America [14]. This trend was formed on the basis of the implementation by Asian seaports of aggressive marketing development strategies, while ports in North America and Europe used mixed complex growth models. They have a significant impact on the local and international competitiveness of both ports and cities. There are dif- ferent models of interaction between ports and cities sea clusters, port industrial development and seaports' development, as well as various combinations of known models [14].

The development of public-private partnership can take the form of a variety of models, the key dimensions of which are the form of ownership of land, regulation and operations (Table 8). At the same time, the seaports' development, specializing in the provision of commodity flows, is becoming secondary, although there are differences between countries as they participate in logistics chains.

The positions of seaports on the world market change due to various reasons - changing the name, changing the specialization of the port and its main customers (for example, Gothenburg $(0.18 \%)$ - cars, Las Palmas $(0.29 \%)$ passenger ships). Legislative changes, the implementation of national strategies and local investment projects can also change the volume of commodity flows for some time. In recent years, national seaport development strategies have been most actively implemented in China (the share has increased from $24.9 \%$ to $29.8 \%$ ), South Korea (6 \%), Australia ( $4.7 \%$ to $6.4 \%$ ). However, the positions of other countries are deteriorating - the United States $(13.1 \%$ and $10.9 \%)$, France $(2.2 \%$ and $1.6 \%)$, Germany $(2.1 \%$ to $1.6 \%)$, Canada (1.7\%), Morocco, the Russian Federation $(1.8 \%$ and $1.4 \%)$.

So in France over the past 30 years, there have been two stages of decentralization (in 1992 and 2004), and the 2008 Law on Reforming Seaports has promoted the adoption in 2016 of the Blue Economy Act, which covers the development and exploitation of global ocean capabilities. A special place in the last law is occupied by the issues of ensuring the autonomy of ports, especially the main seaports, and providing them with the tools for developing strategies for commercial expansion [42].

It is necessary to highlight the priority directions for the development of French seaports, which should find their reflection in the development strategy of the seaports of Ukraine, namely:

- integration of port policy with economic and territorial policies;

- strengthening of activities and cooperation of port communities among themselves;

- improvement of business models of ports;

- massification and increase of traffic safety, especially ensuring interconnections with the ground infrastructure;

- improvement of the port's image.

The process of decentralization of the development of port infrastructure implies an increase in the industry's readiness to operate in competitive seaports among themselves, as well as with foreign competitors. The international competitiveness and efficiency of the industry is formed for a long time and depends on many institutional players, therefore all related subjects, including internal dry ports, should be ready for the transition to competitive conditions [18].

Therefore, conducting surveys, SWOT analysis, benchmarking should become tools that are mainly used in deciding on decentralization, including issues of strategic planning, location of facilities, increased productivity, development of transport infrastructure. 
Map of the global port market in 2008-2015, million tons (ports

\begin{tabular}{|c|c|c|c|c|}
\hline \multirow{2}{*}{$\begin{array}{l}\text { Growth of mar- } \\
\text { ket share }\end{array}$} & \multicolumn{4}{|c|}{ Subjects by market share size } \\
\hline & $\begin{array}{l}\text { Leader, } \\
3.2 \%\end{array}$ & $\begin{array}{c}\text { Strong competitive position, } \\
0.51-2.8 \%\end{array}$ & $\begin{array}{c}\text { Weak competitive position, } \\
0.5-0.16 \%\end{array}$ & $\begin{array}{l}\text { Outsider, } \\
<0.16 \%\end{array}$ \\
\hline $\begin{array}{l}\text { Rapid improve- } \\
\text { ment of the } \\
\text { competitive posi- } \\
\text { tion, }>40 \%\end{array}$ & - & $\begin{array}{l}\text { Tangshan, Xiamen, China; port of } \\
\text { Hedland, Australia; Southampton, } \\
\text { United Kingdom; Lianyungang, Ri- } \\
\text { zhao, Yantai, Nanjing, Dingdao, China; } \\
\text { Newcastle, Australia }\end{array}$ & $\begin{array}{l}\text { Callao, Peru; Yuzhniy, Ukraine; Durban, South Africa; } \\
\text { Banjarmasin, Indonesia; Flushing, the Netherlands; } \\
\text { Yanbu, Saudi Arabia; Yanbu, Saudi Arabia; Chittagong, } \\
\text { Bangladesh; Jubail, Saudi Arabia; Cartagena, Colombia; } \\
\text { Paradip, India }\end{array}$ & Burgas, Bulgaria \\
\hline $\begin{array}{l}\text { Improvement of } \\
\text { the com- } \\
\text { petitive position, } \\
0-40 \%\end{array}$ & $\begin{array}{l}\text { Shanghai, } \\
\text { China }\end{array}$ & $\begin{array}{l}\text { Nantong, China; Tanjung Pelepas, } \\
\text { Malaysia; Santos, Brazil; Port of } \\
\text { New Saigon, Vietnam; Port-Kelang, } \\
\text { Malaysia; Busan, Kwangyang, Suuth } \\
\text { Korea; Hay Point, Australia; Tubarao, } \\
\text { Brazil; Guangzhou, China; Gladstone, } \\
\text { Australia; Algeciras-La-Linea, Spain; } \\
\text { Corpus Christi, USA; Dalian, Ningbo, } \\
\text { China; Richards Bay, South Africa; } \\
\text { Dampier, Australia; Metro Vancouver, } \\
\text { Canada; Tianjin, China; Dhabi Ports, } \\
\text { United Arab Emirates }\end{array}$ & $\begin{array}{l}\text { Lazaro Cardenas, Mexica; Laem Chabang, Thailand; } \\
\text { Saldanha Bay, South Africa; Taichung, Taiwan; Karachi, } \\
\text { Pakistan; Ambarli, Turkey; Baton Rouge, USA; Para- } \\
\text { nagua, Brazil; Manila, Philippines; Beaumont, USA; } \\
\text { Aliaga, Turkey; Angra dos Reis, Brazil; Riga, Latvia; } \\
\text { Duebec, Canada; New Orleans, USA; Izmit (Kocaeli), } \\
\text { Turkey; Jeddah, Saudi Arabia; Trieste, Italy; Klaipeda, } \\
\text { Lithuania; Bombay, India; Valencia, Spain; Brisbane, } \\
\text { Australia; Tanjung Priok, Indonesia } \\
\end{array}$ & $\begin{array}{l}\text { Gdansk, Poland; Piraeus, Gree- } \\
\text { ce; Narvik, Norway; Las Palmas, } \\
\text { 5pain; Nakhodka, Russia; Ha- } \\
\text { mina/Kotka, Finland; Eastern } \\
\text { Port, Russia }\end{array}$ \\
\hline $\begin{array}{l}\text { Deterioration of } \\
\text { the competitive } \\
\text { position, } \\
-30-0 \%\end{array}$ & $\begin{array}{l}\text { Singapore, } \\
\text { Singapore }\end{array}$ & $\begin{array}{l}\text { South Louisiana, Houston, USA; In- } \\
\text { cheon, South Korea; Rotterdam, the } \\
\text { Netherlands; Antwerp, Belgium; } \\
\text { Ithaki, Brazil; Amsterdam Ports, } \\
\text { Netherlands; Kobe, Japan; Chiba, } \\
\text { Japan; Ulsan, South Korea; Hong } \\
\text { Kong, China; Hamburg, Germany; } \\
\text { Qinhuangdao, China; Kitakyushu, } \\
\text { Japan; Nagoya, Japan; Shenzhen, } \\
\text { China; New York/New Jersey, USA } \\
\end{array}$ & $\begin{array}{l}\text { Jawaharlal Nehru India; The Corps of Christ, USA; } \\
\text { Hakata, Japan; Alexandria, Egypt; Ports of Fremantle, } \\
\text { Australia; The state of Texas, USA; Dasan, South } \\
\text { Korea; Botas, Turkey; St. Louis, Lake Charles USA; } \\
\text { Sydney ports, Australia; Tokyo, Japan; Seppeta, Brazil; } \\
\text { Liverpool/Mercy-board, Great Britain; New Mangalore, } \\
\text { Visakhapatnam India; Los Angeles, Pascagoula, Balti- } \\
\text { more, USA; Tarragana, Spain; Bandar Abbas, Bandar } \\
\text { Khomeini, Iran; San Sebastiao, Brazil; Bremerhaven, } \\
\text { Germany; Long Beach, Savannah, USA; Milford Haven, } \\
\text { United Kingdom; San Lorenz-San Martin, Argentina; } \\
\text { Livorno, Genoa, Italy; Calcutta, India; Constanta, } \\
\text { Romania; Barcelona, Spain; Grimsby and Imming- } \\
\text { ham, UK; Zeebrugge, Belgium; Gothenburg, Sweden; } \\
\text { Novorossiysk, Russia; Chennai, India; Nantes Saint- } \\
\text { Nazairs, Franc; MinaSulman, Bahrain; Aratu, Brazili } \\
\text { Osaka, Japan; Mobile, Hampton Raads, USA; Calais, } \\
\text { France; Saint-Petersburg, Russia; London, Great Bri- } \\
\text { tain; Marseille, France; Le Havre, France; Pittsburgh, } \\
\text { Plaquemines, USA; Bergen, Norway; Taranto, Italy }\end{array}$ & $\begin{array}{l}\text { Skoldwick, Finland; Two harbors, } \\
\text { USA; Lakeso, Portugal; Naples, } \\
\text { Gioia Tauro, Italy; Murmansk, } \\
\text { Russia; Santa Cruz de Tenerife, } \\
\text { Spain; Gdynia, Poland; Szcze- } \\
\text { cin-Swinoujscie, Poland; Fe- } \\
\text { lixstow, UK; Ghent, Belgium; } \\
\text { Auckland, USA; Cartagena, Spain; } \\
\text { Rouen, France; Honolulu, USA; } \\
\text { Belfast, United Kingdom; Tuapse, } \\
\text { Russia; Thessaloniki, Greece; } \\
\text { Port Everglades, Port Arthur, } \\
\text { Portland, Oregon, USA; Savona, } \\
\text { Venice, Italy; Rostock, Germany; } \\
\text { Tacoma, USA; Lubeck, Germany; } \\
\text { Ravenna, Italy; Charleston, Seat- } \\
\text { tle, United States }\end{array}$ \\
\hline $\begin{array}{l}\text { Rapid deteriora- } \\
\text { tion of the com- } \\
\text { petitive position, } \\
\quad<-30 \%\end{array}$ & - & Yokohama, Japan; Kaohsiung, Taiwan & $\begin{array}{l}\text { Dunkirk, France; Primorsk, Russia; Duluth-Sove- } \\
\text { reign, USA; Pohang, South Korea; Tees and Hartlepool, } \\
\text { UK; Huntington, USA; Melbourne, Australia; Yanbu, } \\
\text { Saudi Arabia; Bintulu, Malaysia }\end{array}$ & $\begin{array}{l}\text { Livorno, Italy; Philadelphia, USA; } \\
\text { Richmond, California, Valdez, USA; } \\
\text { Bilbao, Spain; Odessa, Ukraine; } \\
\text { Boston, USA; Chicago, Tampa, } \\
\text { Jacksonville, Paulsboro, USA; } \\
\text { Wilhelmshaven, Germany; Fourth } \\
\text { ports, Great Britain; Mormugao, } \\
\text { India; Yingkou, China }\end{array}$ \\
\hline
\end{tabular}

Note: names of ports in the redaction of the American Association of Port Administrations.

Table 6

Map of the global port market in 2008-2015, million tons (countries)

\begin{tabular}{|c|c|c|c|c|}
\hline \multirow[b]{2}{*}{ Growth of market share } & \multicolumn{4}{|c|}{ Subjects by market share size } \\
\hline & $\begin{array}{l}\text { Leader, } \\
>29.8 \%\end{array}$ & $\begin{array}{l}\text { Strong competitive } \\
\text { position, } 2.2-10.8 \%\end{array}$ & $\begin{array}{l}\text { Weak competitive position, } \\
0.16-2.0 \%\end{array}$ & $\begin{array}{l}\text { Outsider, } \\
<0.01 \%\end{array}$ \\
\hline $\begin{array}{l}\text { Rapid improvement of the com- } \\
\text { petitive position, }>25 \%\end{array}$ & - & Australia & $\begin{array}{l}\text { Peru; Bangladesh; Colombia; Mexica; Thailand; } \\
\text { South Africa; Vietnam }\end{array}$ & Bulgaria \\
\hline $\begin{array}{l}\text { Improvement of competitive po- } \\
\text { sition, } 0-25 \%\end{array}$ & China & $\begin{array}{l}\text { South Korea; Brazil; } \\
\text { Malaysia }\end{array}$ & $\begin{array}{l}\text { Indonesia; Pakistan; Ukraine; Philippines; Estonia; Canada; } \\
\text { United Arab Emirates; Turkey; Lithuania; Poland; Finland }\end{array}$ & - \\
\hline $\begin{array}{l}\text { Deterioration of the competitive } \\
\text { position, }-19-0 \%\end{array}$ & - & $\begin{array}{l}\text { Netherlands; Singapore; } \\
\text { India; USA }\end{array}$ & $\begin{array}{l}\text { Saudi Arabia; Greece; Egypt; Spain; Belgium; United Kingdom; } \\
\text { Iran; Argentina; Norway; Italy }\end{array}$ & Portugal \\
\hline $\begin{array}{l}\text { Rapid deterioration of the com- } \\
\text { petitive position, <-19\% }\end{array}$ & - & Japan & $\begin{array}{c}\text { Taiwan; Germany; Romania; Russia; Sweden; Bahrain; } \\
\text { France; United States }\end{array}$ & - \\
\hline
\end{tabular}


Map of the global port market in 2008-2015, TEU (ports)

\begin{tabular}{|c|c|c|c|c|}
\hline \multirow[b]{2}{*}{ Growth of market share } & \multicolumn{4}{|c|}{ Subjects by market share size } \\
\hline & $\begin{array}{l}\text { Leader, } \\
>28.4 \%\end{array}$ & $\begin{array}{c}\text { Strong competitive position, } \\
6.89-0.79 \%\end{array}$ & $\begin{array}{c}\text { Weak competitive po- } \\
\text { sition, } 0.62-0.29 \%\end{array}$ & $\begin{array}{l}\text { Dutsider, } \\
<0.28 \%\end{array}$ \\
\hline $\begin{array}{l}\text { Rapid improvement of } \\
\text { the competitive position, } \\
>20 \%\end{array}$ & - & $\begin{array}{l}\text { United Kingdom; Mexica; Indo- } \\
\text { nesia }\end{array}$ & $\begin{array}{l}\text { Greece; Portugal; } \\
\text { Bangladesh; Peru }\end{array}$ & $\begin{array}{l}\text { Libya; Myanmar; Nicaragua; Djibouti; Norway; Cambodia; } \\
\text { Poland; Kuwait; Suriname; Sierra Leone; Slovenia; Liberia; } \\
\text { Guinea; Maldives; Tanzania; Kenya }\end{array}$ \\
\hline $\begin{array}{l}\text { Improvement of competi- } \\
\text { tive position, } 0-20 \%\end{array}$ & China & $\begin{array}{l}\text { Germany; Turkey; Philippines; } \\
\text { Saudi Arabia; Vietnam; South } \\
\text { Korea; Sri Lanka; United Arab } \\
\text { Emirates; Malaysia; India; Brazil }\end{array}$ & $\begin{array}{l}\text { New Zealand; } \\
\text { Colombia; Chile; } \\
\text { Malta; Morocca }\end{array}$ & $\begin{array}{l}\text { Congo; Mauritius; Latvia; Ecuador; Namibia; Lithuania; Guate- } \\
\text { mala; Ghana; Croatia; Datar; Papua New Guinea; Cuba; Costa } \\
\text { Rica; Senegal; Belize; Mozambique; Bulgaria; Salvador; } \\
\text { Finland; Iceland; Mauritania; Brunei Darussalam; Saint } \\
\text { Kitts and Nevis; Uruguay; Barbados; Cameroon; Romania; } \\
\text { Antigua and Barbuda; Jordan; St. Vincent and the Grenadines }\end{array}$ \\
\hline $\begin{array}{l}\text { Deterioration of the } \\
\text { competitive position, } \\
-20-0 \%\end{array}$ & - & $\begin{array}{l}\text { United States; Thailand; France; } \\
\text { Spain; Canada; Australia; Taiwan, } \\
\text { China; Panama; Netherlands; Ja- } \\
\text { pan; Italy; Singapore; Belgium }\end{array}$ & $\begin{array}{l}\text { Pakistan; Russian } \\
\text { Federation; Sauth } \\
\quad \text { Africa; Israel }\end{array}$ & $\begin{array}{l}\text { Sudan; Georgia; Samoa; Sweden; Honduras; Lebanon; } \\
\text { Madagascar; Ireland; Tunisia; Ivory Coast; Dominican Re- } \\
\text { public; Nigeria; Haiti; Grenada; Bahamian Islands; Algeria; } \\
\text { Benin; Equatorial Guinea; Fiji; Gambia }\end{array}$ \\
\hline $\begin{array}{l}\text { Rapid deterioration of the } \\
\text { competitive position, } \\
<-20 \%\end{array}$ & - & Egypt; Hong Kong, China SAR & Oman; Iran & $\begin{array}{l}\text { DR Congo; Denmark; Syria; Ukraine; Gabon; Estonia; } \\
\text { Cyprus; Guyana; Jamaica; Argentina; Trinidad and Tobaga; } \\
\text { Bahrain; St. Lucia; Angola; Ga; Venezuela; Yemen; Dominica }\end{array}$ \\
\hline
\end{tabular}

Map of the global port market in 2008-2015, TEU (countrie )

\begin{tabular}{|c|c|c|c|c|}
\hline \multirow{2}{*}{$\begin{array}{l}\text { Growth of } \\
\text { market share }\end{array}$} & \multicolumn{4}{|c|}{ Subjects by market share size } \\
\hline & $\begin{array}{l}\text { Leader, } \\
>5 \%\end{array}$ & $\begin{array}{c}\text { Strong competitive position, } \\
0.47-5 \%\end{array}$ & $\begin{array}{c}\text { Weak competitive position, } \\
0.11-0.46 \%\end{array}$ & $\begin{array}{l}\text { Outsider, } \\
<0.1 \%\end{array}$ \\
\hline $\begin{array}{l}\text { Rapid im- } \\
\text { provement of } \\
\text { the competi- } \\
\text { tive position, } \\
\quad>25 \%\end{array}$ & - & $\begin{array}{l}\text { Colombo, 5ri Lanka; Barcelona, } \\
\text { Spain; Yokohama, Japan; Mina Bi- } \\
\text { sut (Salalah), Oman; Hamburg, Ger- } \\
\text { many; Nagoya, Japan }\end{array}$ & \begin{tabular}{|l|} 
Penang, Malaysia; Taranta, Italy; Constanta, Romania; \\
Kitakyushu, Japan; Chornomorsk, Ukraine; London, \\
Great Britain; Las Palmas, Spain; Buenaventura, Colom- \\
bia; Zeebrugge, Belgium; San Juan, USA; Damietta, Egypt; \\
Livorno, Italy; Pointe-Noire, Congo; Odessa, Ukraine; \\
Anchorage, USA; Freeport, Bahamas; Johor, Malaysia; \\
Bandar Abbas, Iran; Kingston, Jamaica; Saint-Peters- \\
burg, Russia; Izmir, Turkey; Port Everglades, USA; \\
Liverpool/Mercy-board, Great Britain; Talcahuano/San \\
Vicente, Valparaisa, Chile; Haifa, Israel; Auckland, New \\
Zealand; Abidjan, Cote d'Ivoire; Montreal, Canada
\end{tabular} & $\begin{array}{l}\text { Piraeus, Greece; Amsterdam Ports, } \\
\text { Netherlands; Port Elizabeth, South } \\
\text { Africa; Aden, Yemen; Helsingborg, } \\
\text { Sweden; Salerno, Italy; Tees and } \\
\text { Hartlepool, UK; Limassol, Cyprus; } \\
\text { Iquique, Chile; Kuching, Malaysia; } \\
\text { El-Sokhna, Egypt; Aarhus, Den- } \\
\text { mark; Lame, Togo; Helsinki, Fin- } \\
\text { land; Shimizu, Japan }\end{array}$ \\
\hline $\begin{array}{l}\text { Improvement } \\
\text { of competi- } \\
\text { tive position, } \\
0-25 \%\end{array}$ & $\begin{array}{l}\text { Hong Kong, } \\
\text { China; } \\
\text { Singapore, } \\
\text { Singapore }\end{array}$ & $\begin{array}{l}\text { Gioia Tauro, Italy; Bremen/Bremer- } \\
\text { haven, Germany; Le Havre, France; } \\
\text { Los Angeles, USA; Durban, South } \\
\text { Africa; Kobe, Japan; Kaohsiung, Tai- } \\
\text { wan; Tokyo, Japan; Antwerp, Bel- } \\
\text { gium; Shenzhen, China; Felixstowe, } \\
\text { UK; Long Beach, USA; Rotterdam, } \\
\text { the Netherlands; Nhava Sheva, Jawa- } \\
\text { harlal Nehru, India; New York/New } \\
\text { Jersey, USA; Metro Port Vancouver, } \\
\text { Canada }\end{array}$ & $\begin{array}{l}\text { Puerto Cortes, Honduras; Bin Dasim, Pakistan; Hami- } \\
\text { na/Kotka, Finland; Livorno, Italy; Gothenburg, Sweden; } \\
\text { Osaka, Japan; Rio Grande, Brazili; Auckland, USA; Puerto } \\
\text { Cabello, Venezuela; La Spezia, Italy; San Antonio, Chile; } \\
\text { Port Said (West), Egypt; Bilbao, Spain; Honolulu, Miami, } \\
\text { USA; Dublin, Ireland; Hakata, Japan; Montevideo, Uru- } \\
\text { guay; Cape Town, South Africa; Veracruz, Mexicc; } \\
\text { Shuvaikh, Kuwait; Tacoma, USA; Ports of Fremantle, } \\
\text { Australia; Limon-Moine, Costa Hica; Bangkok, Thailand; } \\
\text { Manzanillo, Panama; Caucedo, Dominican Republic; } \\
\text { Taichung, Taiwan; Houston, Charleston, Hampton Roads, } \\
\text { USA; Buenos Aires, Argentina; Melbourne, Australia; } \\
\text { Paranagua, Brazil; Colon, Panama }\end{array}$ & $\begin{array}{l}\text { Banjarmasin, Indonesia; Klaipeda, } \\
\text { Lithuania; Trieste, Italy; Rio de Ja- } \\
\text { neiro, Brazil; We are pleased, Tunis; } \\
\text { Istanbul (Haydarpasa), Turkey; } \\
\text { Ulsan, Sauth Korea; Halifax, Ca- } \\
\text { nada; Tuticorin, India; Venice, Italy; } \\
\text { Cotonou, Benin; Naples, Italy; Port } \\
\text { Sudan, Sudan; Dakar, Senegal; } \\
\text { Cebu, Philippines; Novorossiysk, } \\
\text { Russia; Seppeta, Brazil; Douala, } \\
\text { Cameron; La Guaira, Venezuela }\end{array}$ \\
\hline $\begin{array}{l}\text { Deterioration } \\
\text { of the competi- } \\
\text { tive position, } \\
-25-0 \%\end{array}$ & $\begin{array}{c}\text { Shanghai, } \\
\text { China }\end{array}$ & $\begin{array}{l}\text { Valencia, Spain; Tanjung Priok, Indo- } \\
\text { nesia; East Port Said, Egypt; Ports of } \\
\text { Dubai, United Arab Emirates; Laem } \\
\text { Chabang, Thailand; Manila, Philip- } \\
\text { pines; Marsaxlokk, Malta; Algeciras- } \\
\text { La-Linea, Spain; Santos, Brazil; Sa- } \\
\text { vannah, USA; Busan, South Korea; } \\
\text { Port-Kelang, Malaysia; Guangzhou, } \\
\text { China; Tanjung Pelepas, Malaysia; } \\
\text { Jeddah, Saudi Arabia; Tianjin, China }\end{array}$ & $\begin{array}{l}\text { Southampton, United Kingdom; Genoa, Italy; Brisbane, } \\
\text { Australia; Kwangyang, South Korea; Keelung, Taiwan; } \\
\text { Sydney ports, Australia; Beirut, Lebanon; Alexandria } \\
\text { and El Deheyla, Egypt; Jacksonville, USA; Incheon, South } \\
\text { Korea; Madras, India; Aqaba, Jordan; Itajay, Brazil; } \\
\text { Balbaa, Panama; Belavan, Indonesia; Mombasa, Kenya; } \\
\text { Theme, Ghana; Marseille, France; Casablanca, Morocco; } \\
\text { Chennai, India; Dammam, Saudi Arabia; Apapa, Nigeria; } \\
\text { Ashdod, Israel; Callao, Peru; Icel (Mersin), Turkey; } \\
\text { Karachi, Pakistan; Duanzhou, China }\end{array}$ & $\begin{array}{l}\text { Qinhuangdao, China; Altamira, Me- } \\
\text { xico; Calcutta, India; Davao, Phi- } \\
\text { lippines; Lyttelton, Australia; Port } \\
\text { Louis, Mauritius; Santo Tomas de } \\
\text { Castilla, Honduras; Dar es 5a- } \\
\text { laam, Tanzania; Vladivostok, hus- } \\
\text { sia; Gdynia, Poland; Koper, Croatia; } \\
\text { Luanda, Angola }\end{array}$ \\
\hline $\begin{array}{l}\text { Rapid dete- } \\
\text { rioration of } \\
\text { the competi- } \\
\text { tive position, } \\
\quad<-25 \%\end{array}$ & - & $\begin{array}{l}\text { Lianyungang, Qingdao, Xiamen, Ning- } \\
\text { bo, China; Port of Saigon, Vietnam; } \\
\text { Dalian, China }\end{array}$ & $\begin{array}{l}\text { Manzanillo, Mexico; Seattle, USA; Chittagong, Bangla- } \\
\text { desh; Ambarli, Turkey; Guayaquil, Ecuador; Fuzhou, } \\
\text { China; KhorFakkan, United Arab Emirates; Nanjing, } \\
\text { Zhongshan, China; Saigon, New Port, Vietnam; Carta- } \\
\text { gena, Colombia; Yuingkou, China }\end{array}$ & $\begin{array}{l}\text { Tin Island, Nigeria; Riga, Estonia; } \\
\text { Baltimore, New Orleans, USA; Mina } \\
\text { Sulman, Bahrain; San Francisca } \\
\text { do Sul, Brazil; Lisbon, Portugal; } \\
\text { Djibouti, Djibouti; Cristobal, Pana- } \\
\text { ma; Prince Rupert, Canada; Port of } \\
\text { Tauranga, New Zealand; Gdansk, } \\
\text { Poland; Lakeso, Portugal; Ngqura, } \\
\text { South Africa }\end{array}$ \\
\hline
\end{tabular}


A successful transition to a public-private model of seaport development is based on a number of critically important factors that enable qualitative risk management. It also implies the possibility of making changes to primary agreements. The experience of Malaysia, in which the transition to a decentralized model of seaport development has been implemented in recent years, can be used to prevent possible problems. Thus, key factors in the successful development of public-private partnership in the port industry of Malaysia, which is included in the group of countries with a strong market position $(2.25 \%)$, are considered [53]:

- entrepreneurship and leadership with the support

of the society;

- qualitative selection of projects and conducive investment environment;

- strengthening of the consortium by a justified concessionaire;

- advantages of successful technological solutions;

- clear delineation of financial conditions;

- risk management with the involvement of guaran-

tors, convenient transfer conditions, economic viability and readiness for future growth and challenges.

In addition, among the factors for the successful development of partnerships in the port industry are also called support for top management of subjects, mutual trust, effective coordination, communication and conflict resolution, adequate provision of resources, and the experience of successful partnership. And also include longterm dedication, continuous improvement and training.

One of the attributes of the processes of decentralization in the port industry is the presence of conflicts, especially between the state and private institutions, successful and timely resolution of which contributes to the competitiveness of seaports. As the results of the bibliographic analysis of the leading sources of information on the port business demonstrate, such conflicts are characteristic of both developed and developing countries [45]. Therefore, proper training of personnel, preliminary justification of possible scenarios, clear documentation of agreements are prerequisites for international competitiveness of seaports.

Modern seaports should adapt to dynamic changes in shipbuilding, logistics and market conditions [46]. Examples include the formation of container transport alliances, increased vessel sizes, consolidation processes in the shipbuilding and logistics market, increased attention to information flows and technologies, and the reconfiguration of distribution networks. In modern seaports there is a customs clearance of goods, their storage, including responsible, expedition, forwarding, processing, packaging, distribution, consolidation, reloading, etc. This requires appropriate investments and personnel whose competencies were written earlier [50]. In general, it is necessary to name the improvement of the business competencies of the management personnel, which include the issues of pricing for port services, port marketing mix, market segmentation, port marketing systems and marketing communication tools.

In South Korea, which operates in the regime of the island and occupies $6.01 \%$ of the world market, the realization of the economic miracle became possible due to significant investments in the development of port infrastructure. In fact, the ports, which in this country are divided into two categories - international and local (coastal), are managed on the basis of a mixed form. It combines government regulation and private management with mixed ownership of port land (highlighted by a dark cast in Table 9). The main changes in the model of the seaports' development, the purpose of which is increasing the competitiveness of key ports, occurred after 2003, and before that, there is an active development of state regulation bodies and investments in the development of basic infrastructure. In the process of decentralization, both privatization and pseudo-privatization took place, as a form of increasing private participation in the functioning of ports, for example, on the basis of concession agreements. The essence of decentralization is the transfer of rights from state regulators to local authorities and port administrations, which, under the influence of internationalization and competitive challenges, are also actively improving their own organizational management structures.

Table 9

Matrix of models of port management depending on the form of ownership

\begin{tabular}{|c|c|c|c|c|}
\hline \multirow{2}{*}{ Type of ownership } & \multicolumn{3}{|c|}{ Port functions } & \multirow{2}{*}{ Monopoly } \\
\cline { 2 - 4 } & Regulator & Landowner & Operator & \\
\hline state & state & state & state & state \\
\hline public-private & state & state & private & market \\
\hline private-public & state & private & private & market \\
\hline private & private & private & private & private \\
\hline
\end{tabular}

Note: compiled by the authors on the basis of [48].

6.2. Active position of the state. Most modern seaportsleaders are characterized by a profound development of public-private cooperation (PPC), as one of the factors that determine the competitiveness of the provided services. The effectiveness of the PPC development, the duration of which varies from three to more than 30 years, depends on such factors as [44]:

- concreteness and accuracy of the concession agreement;

- ability to properly identify and distribute risks;

- technical feasibility of the project;

- commitments made by partners;

- attractiveness of the package of financial conditions, clarity in determining the responsibilities of the parties; - presence of a strong private consortium and a rea-

listic assessment of the cost/benefit ratio.

One of the most striking examples is the participation of the US federal government in the implementation of the project for the development of an intermodal internal transport corridor. It combines the interests of private, state and local authorities, as well as various types of transport (ports, railways and roads, special transport) [43]. In general, the critical factors of the development of the State Emergency Service can be divided into the following groups: economic, financial, legal, political, procedural, social, structural and technical.

The main thing in the PPC development is the fundamental desire of the state to use its capabilities, which is appropriately formalized in the regulatory system. So, the decision to use private investments for the development of ports and other infrastructure several years ago was taken in the Russian Federation. For example, it was planned to provide $70 \%$ of the resources for the development of the multifunctional port Bronka (part of the large port of St. Petersburg) at the expense of private investors.

Scientific and educational factors are an invariable component of a highly effective business, which domestic 
seaports should become. In 2006, an international League of Universities was established in the port cities, which brought together representatives from 12 countries [54]. It functions, first of all, as a knowledge sharing platform and aims at improving the quality of interconnections between cities, seaports and universities.

The training modules of one of the world's largest container transport operators CMA CGM evolved over 20 years, which resulted in the creation of a corporate university CMA CGM Academy. It implements the fundamental ideas of the concept of lifelong learning for training both new and existing employees. According to the company, this is part of the strategy for anticipating and the desire to combine internal resources and benefits [25]. More than 400 trainings are implemented by the company in the format of e-learning, which allows to effectively preserve and multiply competitive advantages. The achievements of one company can show opportunities for Ukraine, which had a developed network of training, which in the future can be prepared for the world market as a whole.

Constant updating of technologies, as well as maritime safety standards (for example, the adoption in 2017 of ISO 20519) require not only appropriate training of personnel, but also capital investments [16]. One of the highly effective areas of training and upgrading of managers and employees of seaports by the Dutch is the use of simulations and simulation simulations [33].

The functioning of recruiting agencies, training of personnel, the development of ICT infrastructure, cybersecurity and software, management, design, research and construction services, formation of networks and logistics chains are examples of the socialization of port services. These functions, which are important for the seaports' development, are effectively implemented in the world by private structures. The service industry as a whole is characterized by high private capital participation, which is not ready to participate in long-term infrastructure projects such as seaports, which returns to PPC as the most justified development model.

Projects for the development of cooperation for the formation of port clusters should take into account the scientific and educational component that can bind the subjects into a single system. Thus, the researchers [55] propose the development of a competitive Mediterranean cluster to use the opportunities for joint staff training and employee exchange. Among the mandatory ways to overcome difficulties (among them corruption, which has been intensified in Ukraine as well), the development of China's maritime port sector in 2014 is called the improvement of training and staff training. And also the acceleration of scientific research and technology [46].

6.3. Port expansion of China. The development of China's main 37 seaports demonstrates an effective implementation of the strategy of gradual decentralization. The effectiveness of the functioning of seaports is indicated by the fact that China is the world's leading exporter of goods, the main share of which the country sends by sea. The port industry of the PRC went through three main stages of development:

1) 1949-1984 - integration and control of the Ministry of Communications;

2) 1985-2001 - joint management of the Ministry and local port administrations;

3) since 2002 - management of local port administrative offices, with a large share of private capital participation [47].
In fact, the principle of decentralization has been actively introduced since 2004, when the Law on Ports was adopted, which should become more autonomous and commercially oriented. China managed to attract foreign investment in the development of port infrastructure, even despite the restriction of foreign share of $49 \%$. In the seaports' development, both enterprises and local authorities are actively involved. In the last 2 stages, the instrument of creating free (special) economic zones was actively used, especially for the development of container terminals and attraction of trade flows.

Decentralization of China's maritime port industry is accompanied by a number of accompanying processes. One of them is the purposeful participation of Chinese state enterprises in the development of foreign ports, especially those that are in the sphere of interests of the revival of the silk route. So, the largest shipping company of China Cosco Pacific in 2016 in Greece acquired 51 \% of the shares of the seaport of Piraeus, which is considered as one of the most important transport nodes of the silk route [46].

Port administrations, which have the status of stateowned enterprises, actually function and develop in a market economy. This forces them to take into account the specifics of the planned economy and use marketing approaches to work with clients and attract investment. Decentralization and trends in slowing trade and economic development have led to the formation of excessive port capacities in China, which are underutilized by $35 \%$, and competition between seaports has increased [46]. At the same time, integrated port clusters are being formed (researchers allocate 7 large port clusters in China), which involve the internal regions of the country through transport corridors and dry ports. Moreover, there is both the attraction of foreign investment and international trade flows, and the active internationalization of companies associated with ports.

\section{SWOT analysis of research results}

Strengths. The dynamic of the market positions of ports and countries on the competitive map of the world port market is demonstrated in the work. Also, a full range of stakeholders, factors for developing competitive positions and key global trends have been identified. Their account and use in the development of the strategy for the seaports' development in Ukraine will take into account the interests of all stakeholders, as well as improve the efficiency of the use of port development factors. In the long run, this should lead to an improvement in the quality of services, an increase in the contribution to GDP and the strengthening of the competitive positions of Ukraine's seaports.

Implementation of the development strategy on a scientific basis, taking into account technological, educational, marketing aspects will allow the seaports of Ukraine:

- increase the volume of cargo processing;

- expand the range of goods being reloaded;

- use the advantageous geographical location of the country at the intersection of transport corridors to increase competitiveness;

- develop market positions;

- carry out research, especially in the field of energy efficiency and resource saving;

- find sources of investments for renewal of production capacities. 
Weaknesses. The main weaknesses are that the development of a quality strategy will require agreement with all stakeholders, which will take time. The formation of a new business model of the ports of Ukraine will also require the attraction of financial resources, modern technologies and highly educated personnel, which should be based on developed links with financial, innovative, scientific and educational systems. The construction and development of these links will require significant successive efforts.

Negative impact of the economic situation in the region reduces the pace of development of most enterprises in Ukraine, including seaports. Limiting the possibilities of accumulating reserves of equity for investment projects significantly hinders the further development of the industry.

Unfortunately, the amount of available materials, as well as the resource of authors' time, also limited the possibility of conducting a deeper analysis. Therefore, the work concentrated on the macroeconomic level, and the microlevel was considered in a minimal amount.

Opportunities. Research results open up significant prospects for attracting domestic and foreign capital, resources and commodity flows to Ukraine, as well as export opportunities. Increasing the competitiveness of Ukraine's seaports will help both to improve their financial performance, and related industries, modes of transport. In these conditions, special attention is paid to the specialization of seaports and individual berths on specific promising types of cargo (container, agro-industrial, energy-efficient, etc.), while maintaining the possibility of unification for other types of cargo.

In further studies of regularities and features of the seaports' development, special attention should be paid to the mechanisms for regulating and stimulating the investment and management activities of individual stakeholders, and pricing. It is also desirable to pay special attention to building the capacity of local authorities, as well as to the interests of producers of goods, as transported goods, and services provided (transportation of users of tourist and recreational services). Advantages and disadvantages of the development strategies of seaports in other countries should also be studied in depth to prevent mistakes and increase the efficiency of implementing the latest strategic solutions in the seaports of Ukraine.

Threats. As demonstrated in the paper, the implementation of development strategies is not a guarantee of improving the competitive positions of ports and related entities. However, quality strategies allow minimizing short- and medium-term losses, and realize the potential in the long term. The key threats to the implementation of Ukraine's seaport development strategies include the lack of political will, not taking into account the interests of all stakeholders, inadequate amounts of capital raising, the inability to acquire modern technologies and personnel hunger. In addition, mistakes in setting priorities (as a result of poor analytical decision support) can have a negative impact.

The implementation of development strategies by competitors and the anticipation of obtaining results may negatively affect the market position of Ukraine as a regional leader in maritime transport. The inefficiency of intersystem and interbranch relations of the port industry (domestic commodity production, tourism, recreation and tourism, etc.) can have a negative impact on both the ports themselves and the country's economy, the quality of socio-economic development. Geopolitical factors (for example, unauthorized construction of a bridge across the Kerch Strait), the severance of established economic ties can also negatively affect the development of the ports of Ukraine.

\section{Conclusions}

1. Systematization of the factors of the seaports' development allows to build a matrix, the use of which contributes to making informed decisions by taking into account components, sources of factors and priorities of stakeholders. Analysis of world experience has revealed the active use of public-private partnerships as a basis for the formation of a national model for the seaports' development. The example of South Korea demonstrates the features of a combination of factors in port management models, depending on the form of ownership. Technological, educational and marketing aspects of the seaports' development become the most influential factors, which, under the conditions of a dynamic situation on the world market, necessitates unique long-term strategies. The main factors have been systematized (Table 3), which necessitate a review of the traditional model of the seaports' development in order to improve its efficiency. The following can be named:

- resource - diversification of sources of resources, including medium- and long-term investments, effective management of them;

- scientific and educational - providing highly qualified personnel, new knowledge, forming competitive models and advantages;

- technological - the moral and physical obsolescence of the infrastructure, the attraction of new technologies, including foreign ones;

- environmental - raising the priorities of sustainable development, taking into account the impact on the environment;

- market - competition from foreign seaports, modes of transport and transport corridors;

- economic - strategic need to ensure national economic security, employment of the population and development of interrelated industries.

2. Generalization of foreign experience allows to form a list of stakeholders, which interests should be taken into account in the development and implementation of strategies for the seaports' development. It is revealed that the development of the infrastructure of the world market occurs in the context of increasing private sector participation, which leads to the strengthening of its control over such strategically important nodes as seaports. The successful seaports' development of the country, regardless of the model chosen, is not possible without a long-term active position of the state, attraction of private investors, and also should be carried out on a modern technological basis.

The development of public-private partnership can take the form of a variety of models, the key dimensions of which are the form of ownership of land, regulation and operations (Table 8). At the same time, the seaports' development, specializing in the provision of commodity flows, is becoming secondary, although there are differences between countries as they participate in logistics chains.

3. A competitive map of the world's port market is built, which allowed to identify its leaders and the position of Ukraine. The map demonstrates the dynamic position of seaports and countries in the infrastructure of the world market. The top ten largest countries in world trade (Table 2), which controls about $50 \%$ of its volume, 
is effectively represented in the world port market (Tables 4,7 ). It consists primarily of developed countries and countries in which transnational corporations move production (China, Mexico), which development strategy priorities include commodity imports and exports of high value-added products. Ukraine and its seaports are characterized by weak and outsider positions on the world map, which is determined by the quality and nature of the implementation of the development strategy.

4. Research results make it possible to offer key directions for managing the competitiveness of Ukrainian seaports. The development strategy for each seaport and the industry as a whole should include the solution of such key components, weighed with all stakeholders:

- risk management in terms of ensuring competitiveness and national security;

- monitoring of competitive positions in the world market; - development of systemic links, especially in the context of the qualitative productivity of scientific, educational and technological factors. The starting point for the formation of effective strategies should be a clear identification of their goals.

It is substantiated that the management of competitiveness of Ukrainian seaports should include:

- participation in international transport corridors, clusters, supply chains and creation of value added;

- development of intermodal nodes on a modern technological basis;

- formation of an effective stakeholder pool (Fig. 2);

- provision of quality basic and related services;

- client-oriented approach, marketing of ports and port cities;

- implementation of the results of scientific and applied research by highly competent personnel;

- participation of private domestic and foreign capital in the development and operation of port infrastructure;

- successful resolution and prevention of conflicts;

- seaports' development as an instrument for attracting international trade flows and enhancing business activity.

5. It is concluded that the most developed countries are characterized by the formation of the chain of sciencetechnology-education-marketing, which makes the greatest contribution to the competitiveness of the country, its companies and seaports. Strong positions of developed countries in the world market are preceded by the intensification of scientific and applied research of various aspects of port competitiveness (Table 1), on the basis of which technologies developed, the concept of competences appeared, and managerial and marketing approaches were improved. The most advanced countries and seaports are characterized by the prioritization of environmental aspects of development, which can be called the next component in this chain.

\section{References}

1. Readiness for the Future of Production Report 2018 // World Economic Forum, 2018. 266 p. URL: http://www3.weforum.org/ docs/ FOP_Readiness_Report_2018.pdf (Last accessed: 18.01.2018).

2. Lagoudis I. N., Jr J. B. R., Salminen J. B. Port Investment Strategies under Uncertainty: The Case of a Southeast Asian Multipurpose Port // The Asian Journal of Shipping and Logistics. 2014. Vol. 30, No. 3. P. 299-319. doi: http://doi.org/10.1016/ j.ajsl.2014.12.003

3. Lachininskiy S. S., Semenova I. V. Pozitsionirovanie mirovogo primorskogo goroda Sankt-Peterburga v Baltiyskom regione // Baltiyskiy region. 2015. No. 3. P. 62-75.
4. Kim D. A Comparison of Efficiency with Productivity Criteria for European Container Ports // The Asian Journal of Shipping and Logistics. 2012. Vol. 28, No. 2. P. 183-202. doi: http:// doi.org/10.1016/j.ajsl.2012.08.003

5. Public-Private Partnerships for the Provision of Port Infrastructure: An Explorative Multi-Actor Perspective on Critical Success Factors / Aerts G. et al. // The Asian Journal of Shipping and Logistics. 2014. Vol. 30, No. 3. P. 273-298. doi: http://doi.org/10.1016/j.ajsl.2014.12.002

6. Ahn W., Lee C., Han J. A Study on the Securement of the Competitiveness of Gyeong-In Port // The Asian Journal of Shipping and Logistics. 2014. Vol. 30, No. 2. P. 243-264. doi: http://doi.org/10.1016/j.ajsl.2014.09.006

7. Ports strategy and logistics challenges: What are the levers for long term vitality? / Fremont A. et al. // Five guidelines for improving the competitiveness of French seaports - TDIE Document presented during the Conference of 11 October 2016 : «Ports strategy and logistics challenges: what are the levers for long term vitality». TDIE Research Council, 2017. 56 p. URL: http://tdie.eu/wp-content/uploads/2017/01/Ports-strategy-and-logistics-challenges-TDIE-report-Oct.-2016.pdf (Last accessed: 15.01.2018).

8. Sayareh J., Alizmini H. R. A Hybrid Decision-Making Model for Selecting Container Seaport in the Persian Gulf // The Asian Journal of Shipping and Logistics. 2014. Vol. 30, No. 1. P. 75-95. doi: http://doi.org/10.1016/j.ajsl.2014.04.004

9. Hanaoka S., Regmi M. B. Promoting intermodal freight transport through the development of dry ports in Asia: An environmental perspective // IATSS Research. 2011. Vol. 35 No. 1. P. 16-23. doi: http://doi.org/10.1016/j.iatssr.2011.06.001

10. Galvao C. B., Wang G. W. Y., Mileski J. Public-Private Interests and Conflicts in Ports: A Content Analysis Approach // The Asian Journal of Shipping and Logistics. 2016. Vol. 32, No. 1. P. 13-22. doi: http://doi.org/10.1016/j.ajsl.2016.03.002

11. Preparation of dry ports for a competitive environment in the container seaport system: A process benchmarking approach / Jeevan J. et al. // International Journal of e-Navigation and Maritime Economy. 2017. Vol. 7. P. 19-33. doi: http://doi.org/ 10.1016/j.enavi.2017.06.003

12. Notteboom T., Yang Z. Port governance in China since 2004: Institutional layering and the growing impact of broader policies // Research in Transportation Business \& Management. 2017. Vol. 22. P. 184-200. doi: http://doi.org/10.1016/j.rtbm.2016.09.002

13. Ilnytskyy D, O., Zinchenko S. H. Poshuk idealnoi modeli transportno-tekhnolohichnoi systemy portu: kompetentnisnyi vymir // Visnyk Odeskoho natsionalnoho universytetu. Seriia «Ekonomika». 2017. Vol. 22, No. 5 (58). P. 87-97.

14. Song D.-W., Lee S.-W. Port governance in Korea: Revisited // Research in Transportation Business \& Management. 2017. Vol. 22. P. 27-37. doi: http://doi.org/10.1016/j.rtbm.2016.11.002

15. Private Involvement in Sustainable Management of Indonesian Port: Need and Strategy with PPP Scheme / Hamzah S. et al. / Procedia Environmental Sciences. 2014. Vol. 20. P. 187-196. doi: http://doi.org/10.1016/j.proenv.2014.03.025

16. Chen S.-L., Jeevan J., Cahoon S. Malaysian Container SeaportHinterland Connectivity: Status, Challenges and Strategies // The Asian Journal of Shipping and Logistics. 2016. Vol. 32, No. 3. P. 127-138. doi: http://doi.org/10.1016/j.ajsl.2016.09.001

17. Sugawara J. Port and hinterland network: a case study of the Crescent Corridor intermodal freight program in the US // Transportation Research Procedia. 2017. Vol. 25. P. 916-927. doi: http://doi.org/10.1016/j.trpro.2017.05.466

18. Calderon M., Illing D., Veiga J. Facilities for Bunkering of Liquefied Natural Gas in Ports // Transportation Research Procedia. 2016. Vol. 14. P. 2431-2440. doi: http://doi.org/10.1016/ j.trpro.2016.05.288

19. Thomson H., Corbett J. J., Winebrake J. J. Natural gas as a marine fuel // Energy Policy. 2015. Vol. 87. P. 153-167. doi: http://doi.org/10.1016/j.enpol.2015.08.027

20. Exports of goods and services // Worldbank Statistics database. World Bank Group. URL: https://data.worldbank.org/indicator/NE.EXP.GNFS.ZS (Last accessed: 17.01.2018).

21. Manginas V., Manoli S., Nathanail E. Enhancing sustainable mobility: A business model for the Port of Volos // Transportation Research Procedia. 2017. Vol. 24. P. 275-279. doi: http:// doi.org/10.1016/j.trpro.2017.05.118 
22. Bogusz W., Artur K. Conditions for Developing a Port City Transport Infrastructure Illustrated with the Example of Szczecin Agglomeration // Transportation Research Procedia. 2016. Vol. 16 P. 566-575. doi: http://doi.org/10.1016/j.trpro.2016.11.053

23. Libardo A., Parolin A. Multicriteria Analysis Evaluating Venice Port Development // Procedia - Social and Behavioral Sciences. 2012. Vol. 48. P. 2545-2554. doi: http://doi.org/10.1016/ j.sbspro.2012.06.1225

24. Awad-Nunez S., Gonzalez-Cancelas N., Camarero-Orive A. Application of a Model based on the Use of DELPHI Methodology and Multicriteria Analysis for the Assessment of the Quality of the Spanish Dry Ports Location // Procedia - Social and Behavioral Sciences. 2014. Vol. 162. P. 42-50. doi: http://doi.org/ 10.1016/j.sbspro.2014.12.184

25. Gogas M., Adamos G., Nathanail E. Assessing the performance of intermodal city logistics terminals in Thessaloniki // Transportation Research Procedia. 2017. Vol. 24. P. 17-24. doi: http:// doi.org/10.1016/j.trpro.2017.05.061

26. Esmemr S., Ceti I. B., Tuna O. A Simulation for Optimum Terminal Truck Number in a Turkish Port Based on Lean and Green Concept // The Asian Journal of Shipping and Logistics. 2010. Vol. 26, No. 2. P. 277-296. doi: http://doi.org/10.1016/ s2092-5212(10)80006-9

27. Review of Maritime Transport $2017 / /$ United Nations Conference on Trade and Development. URL: http://unctad.org/ en/pages/PublicationWebflyer.aspx?publicationid=1890 (Last accessed: 18.01.2018)

28. Financial statements // Ukrainian Sea Ports Authority. URL: http://www.uspa.gov.ua/en/financial-statements (Last accessed: 19.01.2018).

29. Sutomo H., Soemardjito J. Assessment Model of the Port Effectiveness and Efficiency (Case Study: Western Indonesia Region) // Procedia - Social and Behavioral Sciences. 2012. Vol. 43. P. 24-32. doi: http://doi.org/10.1016/j.sbspro.2012.04.074

30. Saxon S., Stone M. Container shipping: The next 50 years. Travel, Transport \& Logistics, 2017. 36 p. URL: https://www. safety4sea.com/wp-content/uploads/2017/10/McKinsey-Container-shipping-The-next-50-years-2017_10.pdf (Last accessed: 20.01.2018).

31. Trade and tariff data // The World Trade Organization (WTO). URL: https://www.wto.org/english/res e/statis e/statis e.htm (Last accessed: 19.01.2018).

32. Rudjanakanoknad J., Suksirivoraboot W., Sukdanont S. Evaluation of International Ports in Thailand through Trade Facilitation Indices from Freight Forwarders // Procedia - Social and Behavioral Sciences. 2014. Vol. 111. P. 1073-1082. doi: http:// doi.org/10.1016/j.sbspro.2014.01.142

33. Seo J., Ha Y. The Role of Port Size and Incentives in the Choice of Location by Port Users: A Game-Theoretic Approach // The Asian Journal of Shipping and Logistics. 2010. Vol. 26, No. 1. P. 49-65. doi: http://doi.org/10.1016/s2092-5212(10)80011-2

34. The Port-city Universities League Secretariat // Yokohama National University. URL: http://www.pul.ynu.ac.jp (Last accessed: 20.01.2018)

35. Bagocius V., Zavadskas K. E., Turskis Z. Multi-Criteria Selection of a Deep-Water Port in Klaipeda // Procedia Engineering. 2013. Vol. 57. P. 144-148. doi: http://doi.org/10.1016/ j.proeng.2013.04.021

36. Ambrosino D., Sciomachen A. Location of Mid-range Dry Ports in Multimodal Logistic Networks // Procedia - Social and Behavioral Sciences. 2014. Vol. 108. P. 118-128. doi: http:/ doi.org/10.1016/j.sbspro.2013.12.825

37. Simulating the Port Wet Infrastructure: Review and Assessment Bellsola Olba X. et al. // Transportation Research Procedia. 2015. Vol. 10. P. 683-693. doi: http://doi.org/10.1016/j.trpro.2015.09.022

38. Port Cooperation Policies in the Mediterranean Basin: An Experimental Approach Using Cluster Analysis / Gianfranco F. et al. // Transportation Research Procedia. 2014. Vol. 3 P. 700-709. doi: http://doi.org/10.1016/j.trpro.2014.10.049

39. Urbanyi-Popiolek I., Klopott M. Container Terminals and Port City Interface - A Study of Gdynia and Gdansk Ports // Transportation Research Procedia. 2016. Vol. 16. P. 517-526. doi: http://doi.org/10.1016/j.trpro.2016.11.049

40. Comprehensive Annual Financial Report. Port of Los Angeles, June 30, 2017 and 2016,115 p. URL: https://www.portoflosangeles.org/Publications/Annual_Financial_Report_FY_2016-17.pdf (Last accessed: 20.01.2018).
41. The experts - CMA CGM ACADEMY: An in-house university with its sights set on the future // CMA CGM. 2017/2018. URL: https://www.cma-cgm.com/media/magazine-article/26/ the-experts-cma-cgm-academy-an-in-house-university-with-itssights-set-on-the-future (Last accessed: 20.01.2018).

42. Lindstad H., Eskeland G. S. Low carbon maritime transport: How speed, size and slenderness amounts to substantial capita energy substitution // Transportation Research Part D: Transport and Environment. 2015. Vol. 41. P. 244-256. doi: http:// doi.org/10.1016/j.trd.2015.10.006

43. The Competitiveness of Global Port-Cities: Synthesis Report ed. by Merk O. // Organisation for Economic Co-operation and Development. URL: https://www.oecd.org/cfe/regional-policy/Competitiveness-of-Global-Port-Cities-Synthesis-Report.pdf (Last accessed: 18.01.2018).

44. Li J., Jiang B. Cooperation performance evaluation between seaport and dry port; case of Qingdao port and Xi'an port // International Journal of e-Navigation and Maritime Economy. 2014. Vol. 1. P. 99-109. doi: http://doi.org/10.1016/j.enavi.2014.12.009

45. Merchandise: Total trade and share, annual // UNCTADSTAT URL: http://unctadstat.unctad.org/wds/TableViewer/tableView.aspx?ReportId=92 (Last accessed: 16.01.2018)

46. ScienceDirect. URL: https://www.sciencedirect.com (Last ac cessed: 18.01.2018)

47. Xu M., Chin A. T. H. Port Governance in China: Devolution and Effects Analysis // Procedia - Social and Behavioral Sciences. 2012 Vol. 43. P. 14-23. doi: http://doi.org/10.1016/j.sbspro.2012.04.073

48. Jeon J. W., Wang Y., Yeo G. T. SNA Approach for Analyzing the Research Trend of International Port Competition // The Asian Journal of Shipping and Logistics. 2016. Vol. 32, No. 3. P. 165-172. doi: http://doi.org/10.1016/j.ajsl.2016.09.005

49. Berestovoy A. M., Zinchenko S. G., Khlopetskaya L. F. Problemy ekspluatatsii i remonta obektov transportno-tekhnologicheskoy sistemy morskogo porta $\mathrm{v}$ usloviyakh ego razvitiya // Sudovozhdenie. 2016. No. 26. P. 175-182.

50. Kazanskaya L. F., Bogomolova A. V. Povyshenie effektivnost gruzovykh perevozok na fone rosta konkurentsii // Sbornik Peterburgskogo gosudarstvennogo universiteta putey soobshheniya «Sotsial'no-ekonomicheskie problemy». 2012. Vol. 4. P. 157-165.

51. Otdelkin N., Kostyunichev D., Sikarev S. Ekologo-ekonomicheskoe obosnovanie parametrov portovykh otkrytykh skladov dlya sypuchikh gruzov // Ekologicheskie sistemy i pribory. 2008. No. 6. P. 60-64.

52. Klepikov V. P. Logisticheskaya infrastruktura Azovskogo morskogo regiona $\mathrm{v}$ novikh usloviyakh // Logistika i upravlenie tsepyami postavok. 2016. No. 1. P. 69-79.

53. Noskov A. Portovaya infrastruktura stran Severnoy Afriki i ee vliyanie na integratsiyu v Sredizemnomor'e // Aziya i Afrika segodnya. 2017. No. 5. P. 21-25.

54. Klepikov V. P. Analiz mul'timodal'nykh perevozok v tsepyakh postavok nefti evropeyskikh stran regiona Atlantiki, Severnogo i Baltiyskogo morey // Logistika i upravlenie tsepyami postavok. 2018. No. 1. P. 3-18.

55. Kuznetsov A. L., Galin A. V. Genezis modeley razvitiya portov v sovremennoy transportnoy nauke // Vestnik Gosudarstvennogo universiteta morskogo i rechnogo flota im. admirala Makarova. 2015. Vol. 2 (30). P. 141-153.

Inytskyy Denys, Doctor of Economic Sciences, Associate Professor, De partment of International Economics, Kyiv National Economic University named after Vadym Hetman, Ukraine, e-mail: ilnytskyy@kneu.edu.ua, ORCID: https://orcid.org/0000-0001-8528-7845

Zinchenko Sergii, PhD, Department of Personnel Management and Labor Economics, Mariupol Institute of the Interregional Academy of Personnel Management, Ukraine, e-mail: fantomac99@gmail.com, ORCID: https://orcid.org/0000-0001-7761-7429

Sayych Oleksandr, PhD, Associate Professor, Department of Marketing, Kyiv National Economic University named after Vadym Hetman, Ukraine, e-mail: savych@kneu.edu.ua, ORCID: https:// orcid.org/0000-0001-5934-9002

Yanchetskyy Oleksandr, Postgraduate Student, Department of Sea Transportation, Azov Maritime Institute of the National University «Odessa Maritime Academy», Mariupol, Ukraine, e-mail: alex.yanchetskyy@gmail.com,ORCID:https://orcid.org/0000-00031686-7795 